\title{
Cold Protection of Leatherleaf Fern Using Crop Covers and Overhead Irrigation in Shadehouses
}

\author{
Robert H. Stamps \\ Central Florida Research and Education Center, Institute of Food and \\ Agricultural Sciences, University of Florida, 2807 Binion Road, Apopka, \\ FL 32703 \\ Additional index words. Rumohra adiantiformis, freeze protection, vase life
}

\begin{abstract}
Four spunbonded crop covers were evaluated for use with and without irrigation for cold protection of leatherleaf fern [Rumohra adiantiformis (Forst.) Ching]. Heavier and less porous covers provided the most protection when used without overthe-crop irrigation. However, differences in cover weight and porosity did not affect temperatures under covers when over-the-crop irrigation was applied. Damage to immature fronds was decreased by $75 \%$ to $99 \%$ when the covers were used alone and by $\mathbf{9 8 \%}$ to $99 \%$ when the covers were used with over-the-crop irrigation. Covers had no effect on frond vase life.
\end{abstract}

Leatherleaf fern is the predominant cut foliage crop in the world and the most valuable floricultural crop produced in Florida (U.S. Dept. of Agriculture, 1990). Leatherleaf fern is a tropical plant that is grown under shade on well-drained, sandy soils and has traditionally been cold-protected in Florida using irrigation water (Stamps and Conover, 1986). Due to concerns about water availability and quality, there is interest in reducing the amount of water necessary for cold protection of this crop. However, immature leatherleaf fern

Received for publication 17 Sept. 1990. Florida Agr. Expt. Sta. J. Series no. R-01597. The assistance of David Brown and support by Kimberly-Clark, Roswell, Ga., and Reemay, Old Hickory, Term., are appreciated. The cost of publishing this paper was defrayed in part by the payment of page charges. Under postal regulations, this paper therefore must be hereby marked $a d$ vertisement solely to indicate this fact. fronds are injured after exposure to temperatures below - 1C (Henley et al., 1980) and are damaged even when being cold-protected using current irrigation water application rates (Korosec, 1990). The immature fronds produced during the winter months are especially important economically since they normally are ready for sale from March through June when demand and prices are highest (Cunningham and Sheehan, 1990). Mature fronds are more cold tolerant and, even though they form a canopy above the immature fronds, they are rarely damaged when irrigation is used for cold protection.

Irrigation water application rate for cold protection can be reduced for this crop during radiation freezes using frost protection sprinklers (Stamps and Mathur, 1982) and by sealing the shadehouse by use of ice (Stamps, 1989). However, the latter technique, a combination of two sprinkler systems (one over the shadehouse to wet the 
ADVECTIVE FREEZE

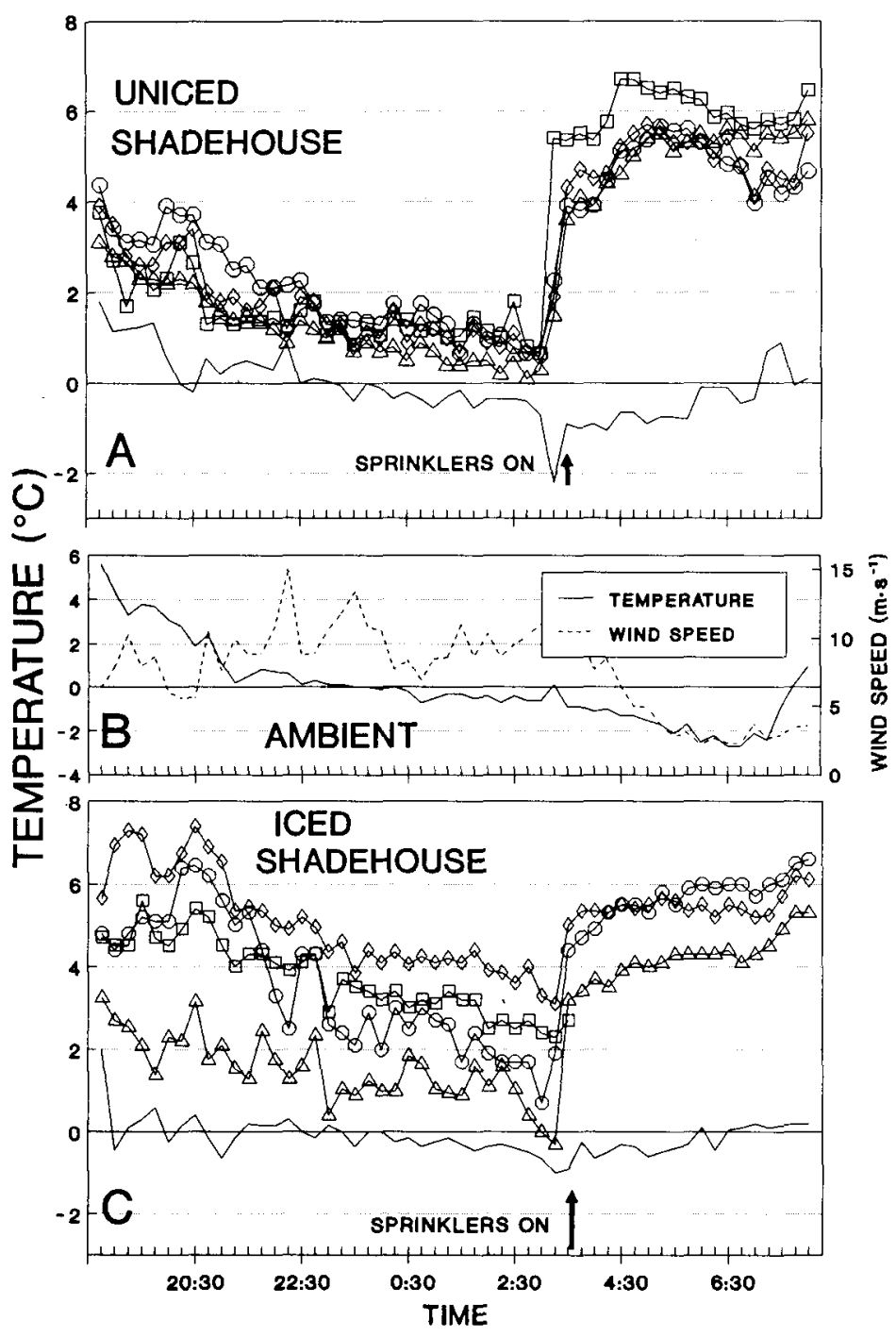

Fig. 1. Ambient air temperatures (-) and wind speeds (--) outside of shadehouses (B), and air temperatures $(-)$ inside uniced $(A)$ and iced $(C)$ shadehouses during an advective freeze on 23-24 Feb. 1989. Temperatures under crop covers of $21 \mathrm{~g}$ polyester $/ \mathrm{m}^{2}(\triangle)$ and spunbonded polypropylene at $20 \mathrm{~g} \cdot \mathrm{m}^{-2}(0), 51 \mathrm{~g} \cdot \mathrm{m}^{-2}(\diamond)$, and $64 \mathrm{~g} \cdot \mathrm{m}^{-2}(\square)$. Each temperature point is the mean of two values.

structure and one over the crop to supply heat) for cold protection, is patented (U.S. Patent and Trademark Office, 1988) and, therefore, the use of this technique involves the payment of royalty fees to the inventor. The use of floating rowcovers in combination with overhead irrigation has been shown to be effective for use on strawberries (Hochmuth et al., 1986), but has not been tried on leatherleaf fern. The objective of these experiments was to evaluate the effectiveness of crop covers and irrigation for coldprotecting leatherleaf fern in iced or united shadehouses.

Post and cable shadehouses $(37 \times 37 \mathrm{~m})$ covered with $73 \%$ woven polypropylene shadecloth located in Crescent City, Fla., were used in these studies. Individual shadehouses were used in experiments where crop covers were tested in united, iced, over-the-crop irrigated, or nonirrigated shadehouses. Overthe-shadehouse irrigation used to seal the shade fabric with ice was achieved with im- the center of the ferneries in a randomized complete-block design with two replications of each rowcover treatment in each shadehouse. The height of the floating rowcovers above the ground was $\approx 0.4 \mathrm{~m}$ except at the edges where the covers were attached to the ground using wire pins. Covers were in place by 1730 HR. Copper-constantan thermocouples (AWG No. 20; $0.8 \mathrm{~mm}$ diam) were attached to wooden stakes $0.3 \mathrm{~m}$ above the ground to monitor temperatures at the level of the immature fronds. Thermocouples were located in the center of each rowcover plot and outside the rowcover plots inside the shadehouses. Additional thermocouples monitored temperatures outside the shadehouses. Temperatures were recorded using a datalogger (PD2064, Esterline Angus, Indianapolis). Wind speeds outside the shadehouses were monitored using an anemometer (Model 2535, Weathertronics, Sacramento, Calif.).

Cold damage to immature leatherleaf fern [R. adiantiformis (Forst.) Ching cv. Baker] fronds was-determined by counting damaged and undamaged fronds in a square meter subplot in each rowcover plot. Vase life of mature fronds harvested after the covers were removed was determined under simulated home/office conditions. Fronds were held in deionized water in rooms that were maintained at $23 \pm 1 \mathrm{C}$ and lighted using fluorescent lamps $\left(15 \mu \mathrm{mol} \cdot \mathrm{s}^{-1} \cdot \mathrm{m}^{-2}\right)$ for 12 $\mathrm{h} \cdot \mathrm{day}^{-1}$. Data were tested using analysis of variance and mean comparisons were made using specific contrasts or Duncan's new multiple range test. Percentage data were transformed using arcsin transformations prior to statistical analysis. All comparisons were made at $P=0.05$.

On 23-24 Feb. 1989, advective freeze occurred with a low of $-2.7 \mathrm{C}$ and a maximum wind speed of $15 \mathrm{~m} \cdot \mathrm{s}^{-1}$ (Fig. 1B). The over-the-shadehouse irrigation was applied

HR and from 2000 to 2025 HR to seal the shadecloth. The over-the-crop irrigation systems were turned on at $0310 \mathrm{HR}$.

In the united shadehouse, temperatures under polypropylene rowcovers generally were higher than outside the rowcovers before over-the-crop irrigation and were higher for all covers after the over-the-crop irrigation started (Fig. 1A). From 2015 HR to 0300 $\mathrm{HR}$ (no irrigation), temperatures under the rowcovers averaged 1.0 to $1.8 \mathrm{C}$ higher than outside the covers, with the more porous PE21 cover providing the least insulation. With over-the-crop irrigation (0345 to $0800 \mathrm{HR}$ ), the air was 5.2 to $5.6 \mathrm{C}$ higher under the covers than outside the covers and there were no differences among the temperatures under the covers. Ice thickness varied with location, duration of water application, and topography of the crop canopy or crop cover; but ice was never thicker than $6 \mathrm{~mm}$.

In the iced shadehouse, temperatures under the crop covers before over-the-crop irrigation were all higher than the controls, with highest temperatures under the polypropylene covers (Fig. 1C). Temperatures under the covers averaged 4.9C (PP51), 3.8C 
RADIATION FREEZE

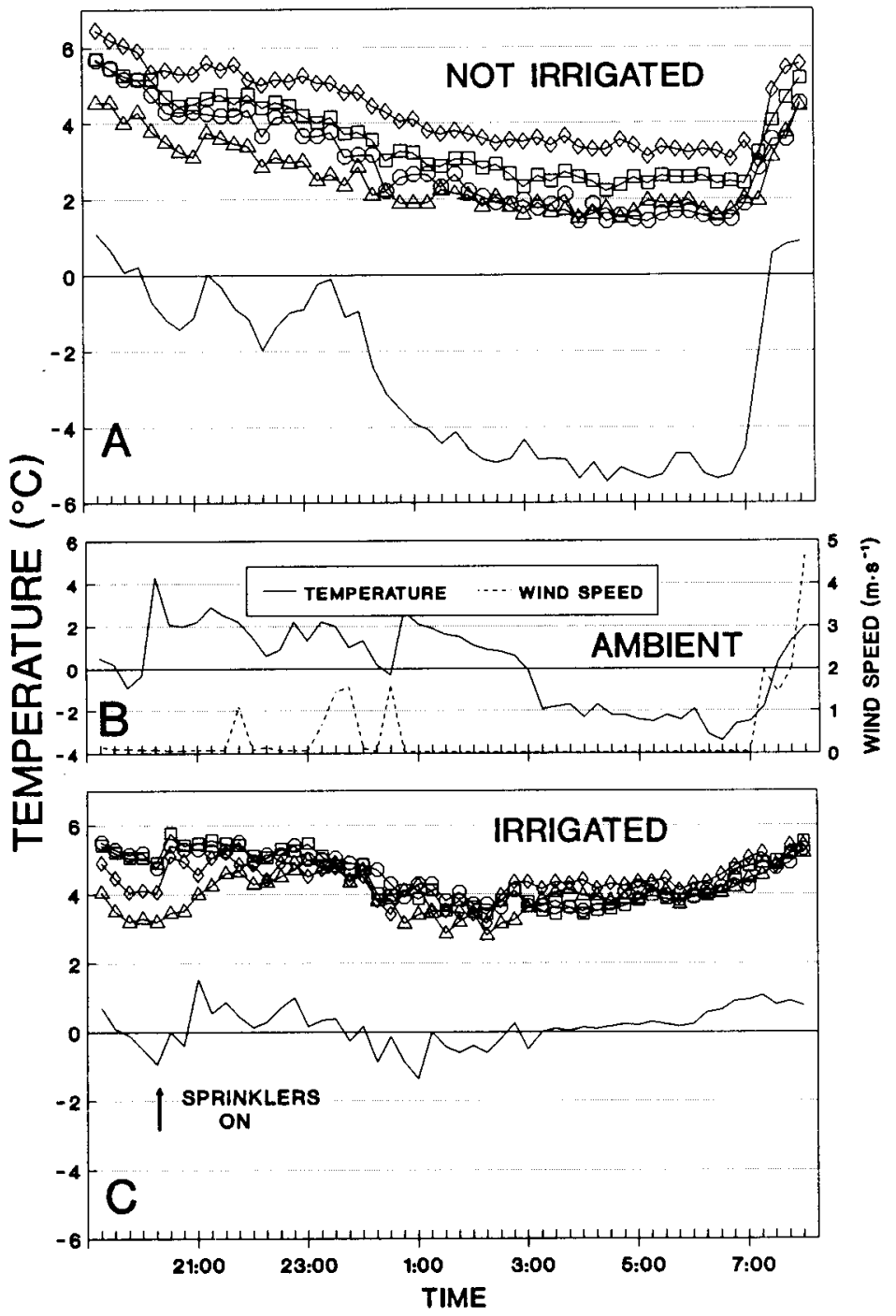

Fig. 2. Ambient air temperatures (-) and wind speeds (---) outside of shadehouses (B), and air temperatures (-) inside shadehouses without (A) and with (C) over-the-crop irrigation during a radiation freeze on 24-25 Feb. 1989. Temperatures under crop covers of $21 \mathrm{~g}$ polyester $/ \mathrm{m}^{2}(\Delta)$ and spunbonded polypropylene at $20 \mathrm{~g} \cdot \mathrm{m}^{-2}(\mathrm{O}), 51 \mathrm{~g} \cdot \mathrm{m}^{-2}(\diamond)$, and $64 \mathrm{~g} \cdot \mathrm{m}(\square)$ ach temperature point is the mean of two values.

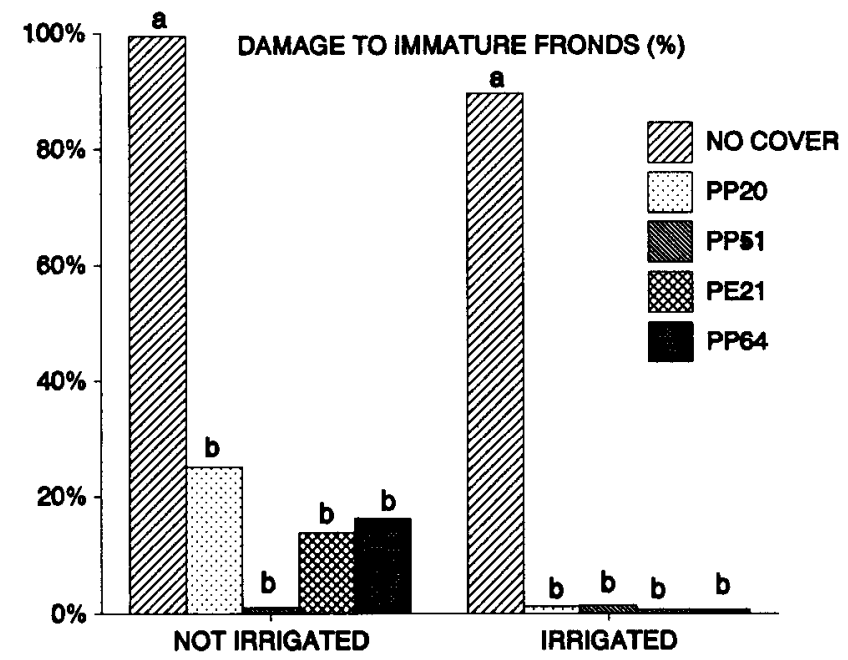

Fig. 3. Percent of immature leatherleaf fern fronds cold-damaged in shadehouses in response to irrigation with over-the-crop sprinkler systems and crop covers. PE21 $=21 \mathrm{~g}$ spunbonded polyester/ $\mathrm{m}^{2}$, PP20, PP51, and PP64 = spunbonded polypropylene at $20 \mathrm{gir}^{\mathrm{n}} \mathrm{z}, 51$ gum- $\mathrm{z}$, and 64 gum- $\mathrm{z}$, respectively. Mean separation within irrigation treatment by Duncan's new multiple range test, $\boldsymbol{P}=$ 0.05
(PP64), 3.4C (PP20) and 1.6C (PE21) higher than without crop covers. With irrigation (0345 to $0800 \mathrm{HR}$ ), temperatures under the covers averaged 4.4 to $5.7 \mathrm{C}$ higher than outside the covers. A malfunction at the time the irrigation was started corrupted the data from the thermocouples under the PP64 covers, but temperatures under the other covers were not different from one another.

On 24-25 Feb. 1989, a radiation freeze occurred with a minimum of $-3.4 \mathrm{C}$ and maximum wind speed of $5.6 \mathrm{~km} \cdot \mathrm{h}^{-1}$ before sunrise (Fig. 2B). Air temperatures in the unirrigated shadehouse were higher under the rowcovers than outside all night long, with the PP51 covers generally maintaining higher temperatures than the lighter PP20 and PE21 covers (Fig. 2A). During the period when the air was at or below 0C (2030-0700 HR), temperatures averaged 5.5, 5.9, 6.6, and 7.3C higher under the PE21, PP20, PP64, and PP51 covers, respectively, than outside.

During that same period, temperatures were also higher under the crop covers than outside the covers in the irrigated shadehouse (Fig. 2C) but there were no significant differences among the temperatures recorded under the various covers. Temperatures ranged from 3.8 to $4.3 \mathrm{C}$ higher under the covers than outside.

Cold damage ratings made 1 week after the freeze showed that crop covers reduced injury to immature fronds by $75 \%$ to $99 \%$ in the unirrigated and by $98 \%$ to $99 \%$ in the irrigated shadehouses (Fig. 3). This reduction in damage to immature fronds is particularly significant because cold injury during prolonged or severe freezes frequently occurs to immature fronds when irrigation alone is used.

Vase life of fronds was not affected by treatments. The mean vase life values were $15.9,16,14.6,14.4$, and 13 days for no cover, PE21, PP51, PP64, and PP20, respectively.

Crop covers appear to offer considerable potential for use as a cold protection tool for leatherleaf fern, with or without the use of overhead irrigation or icing of shadehouses. The combination of irrigation and crop covers may provide greater protection than covers used alone and might allow the use of lower cold protection irrigation rates. Further research on lowest effective water application rates and on low temperature and high wind limits of protection needs to be conducted.

\section{Literature Cited}

Cunningham, J. and P. Sheehan. 1990. Marketing Florida ornamental crops, fresh flowers and ferns, summary 1989. Federal-State Market News Serv. Winter Park, Fla.

Henley, R.W., B. Tjia, and L.L. Loadholtz. 1980. Commercial leatherleaf fern production in Florida. Univ. of Fla., IFAS, Fla. Coop. Ext. Serv. Bul. 191

Hochmuth, G.J., S.R. Kostewicz, S.J. Locascio, E.E. Albreghts, C.M. Howard, and C.D. Stanley. 1986. Freeze protection of strawberries with floating row covers. Proc. Fla. State Hort. Soc. 99:307-311.

HortSCience, Vol. 26(7), July 1991 
Korosec, G.E. 1990. Fern experts tell growers less water use is possible. The Volusian 4(210):1A-2A.

Stamps, R.H. 1989. Icing of shade fabric enhances cold protection of shadehouses during radiation freezes. HortScience 24:517.

Stamps, R.H. and C.A. Conover. 1986. Cut foliage production in Florida. HortScience 21:178, 343. Stamps, R.H. and D.D. Mathur. 1982. Reduced water application rates for cold protection of leatherleaf fern. Proc. Fla. State Hort. Soc. 95:153-155

U.S. Department of Agriculture. 1990. Floricul- ture crops, 1989 summary. U.S. Dept. Agr., Natl. Agr. Stat. Serv., Agr. Stat. Bd., Washington, D.C.

U.S. Patent and Trademark Office. 1988. United States patent 4,763,440. Offic. Gaz. U.S. Patent and Trademark Office 1093(3):1013-1015. 